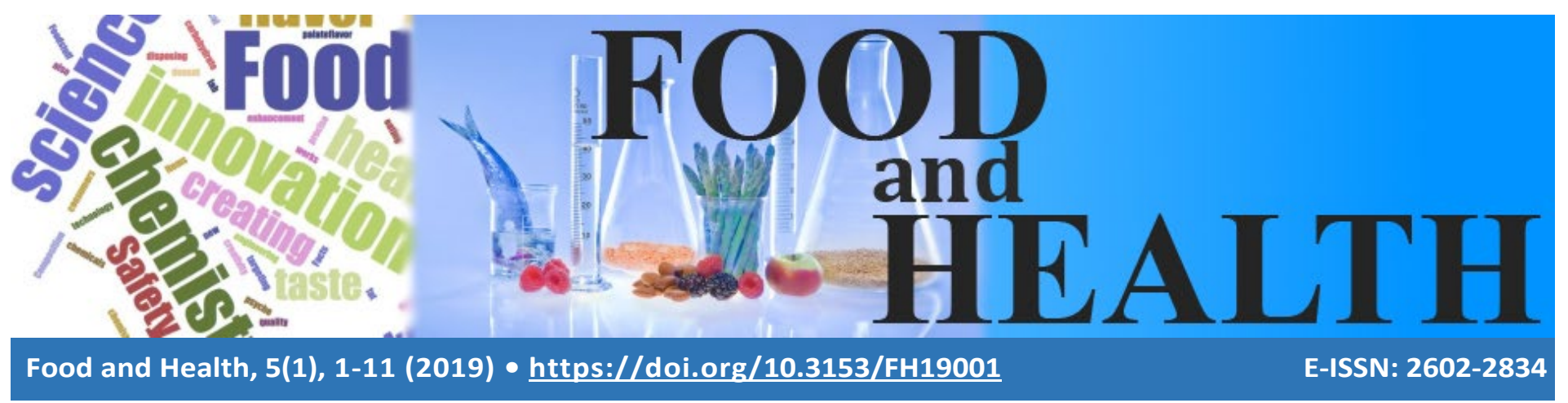

\title{
ANTIBACTERIAL CHARACTERISTICS AND BACTERIA COMPOSITION OF PINEAPPLE (Ananas comosus [Linn.] Merr.) PEEL AND PULP
}

\author{
Faith Osasu-Oviaesu Omorotionmwan ${ }^{1}$ (D), Happiness Isioma Ogwu1 ${ }^{1}$, \\ Matthew Chidozie Ogwu, ${ }^{2,3}$
}

Cite this article as:

Omorotionmwan, F.S., -O., Ogwu, H.I., Ogwu, M.C. (2019). Antibacterial Characteristics and Bacteria Composition of Pineapple (Ananas comosus [Linn.] Merr.) Peel and Pulp. Food and Health, 5(1), 1-11. https://doi.org/10.3153/FH19001

\footnotetext{
${ }^{1}$ Department of Microbiology, Faculty of Life Sciences, University of Benin, Benin City, Nigeria

2 Department of Plant Biology and Biotechnology, Faculty of Life Sciences, University of Benin, Benin City, Nigeria

3 School of Biological Sciences, College of Natural Sciences, Seoul National University, 1 Gwanak-ro, Gwanak-gu, Seoul 08826, South Korea
}

Submitted: 22.01 .2017

Accepted: 05.03.2018

Published online: 03.07.2018

Correspondence:

Matthew Chidozie Ogwu

E-mail: matthew.ogwu@snu.ac.kr

๑Copyright 2019 by ScientificWebJournals

Available online at http://jfhs.scientificwebjournals.com

\begin{abstract}
Pineapple (Ananas comosus [Linn.] Merr.) is a crop with huge economic potentials. In Nigeria, the plant is cultivated in diverse environment and common among fruit vendors. This study is aimed to collect different morphotypes of $A$. comosus from public market to assess the bacterial composition and antibacterial properties using standard procedures. Bacterial colonies obtained from the peel and pulp were in the range of $1.19 \times 10^{4}$ to $9.10 \times 10^{4} \mathrm{CFU} / \mathrm{mL}$. Higher counts were obtained from the peel than the pulp. More so, results implicated the presence of gram-positive bacteria such as Staphylococcus aureus, Streptococcus faecalis, Bacillus species and Clostridium species on pineapple peels and pulps, which may cause contamination of the fruit, health risks to consumers or handlers of the fruits and barks as well as changes during storage and decreased marketability. Greater varieties of bacteria were also recorded from the peel than the pulp. When antibacterial properties were assessed, no zone of inhibition of pineapple juice extracted from the peel was obtained against susceptible clinical isolates (Escherichia coli, Staphylococcus aureus, Streptococcus faecalis and Pseudomonas aeruginosa) using alcohol extract. On the other hand, zone of inhibition in the range of 13 $-16 \mathrm{~mm}$ were obtained from pineapple bark. The results of minimum inhibitory concentration and minimum bactericidal concentration suggests that pineapple bark extract had significant inhibitory and bactericidal effects on the isolates. These suggest the need for health-related ministries, departments and sectors to develop a protocol to monitor and ensure that street vended fruits and foods are fit for consumption and free from pathogens, which may potentially give rise to public health challenges. The antibacterial properties highlighted in this study may also be further explored for manufacturing antimicrobial drugs and products.
\end{abstract}

Keywords: Pineapple (Ananas comosus), Antibacterial characteristics, Bacterial composition, Inhibition zone, Street vended fruit 


\section{Introduction}

The consumption of fresh fruits and vegetables provide essential fibres, minerals, and vitamins, which are necessary to augment our diets and provide health benefits (Alothman et al., 2009; Bhat et al., 2011). They are also important sources of therapeutic and other natural chemicals that may reduce the risk of chronic diseases. Therefore, Kalia and Gupta (2006); Deanna and Jeffrey (2007) recommended the regular consumption of a balanced diet containing sufficient amounts of fruits and vegetables to boost our immunity, prevent mineral-related deficiencies, enhance blood lipid profile and detoxification of our body. According to Hung et al. (2004); Dragsted et al. (2006); Appel et al. (2005); Wiseman (2008), consuming good amounts of fruits, fruit juices and vegetables may control blood pressure, reduce the risk of cardiac diseases, some types of cancer, as well as help, maintain optimum amounts of blood cholesterol. In the same way, consumption of contaminated, rotten or expired fruits, fruit juices and vegetables may lead to food poisoning or serious foodborne diseases. Buck et al. (2003); Tambekar et al. (2008a) reported that over 250 microbes and parasites have been implicated in different foodborne illnesses and diseases including Vibrio cholerae, Escherichia coli, Salmonella typhi and Bacillus cereus, which are responsible for common food poisoning cases.

Juice extract of tropical fruits have gained global relevance for their health benefits. The common ones include banana, guava, grape, orange, pineapple, and watermelon, which are readily available and relatively easy to produce either alone or as a mix and are often sold by street vendors and consumed or served fresh, cooked or preserved in many parts of the world. Pineapple (Ananas comosus [Linn.] Merr., Bromeliaceae) possess pleasant taste and aroma (Abbo et al., 2006; Baruwa, 2013). It is the third most important tropical fruit after Banana and Citrus (Bartolomé et al., 1995). The succulent fruit is perishable and seasonal but contains sugar, protein-digesting enzyme, bromelain, and good amounts of citric and malic acids as well as vitamins, which contributes to its flavour (Joy, 2010; Hemalatha and Anbuselvi, 2013). The average composition of pineapple juice varies depending on geography, season, process and time of harvest (FAO, 2004). The leftover after producing the juice is often discarded, fed to livestock or converted into varieties of finished products. Green pineapple can be used in making pickles while the leaves are used as livestock feed. Some important byproducts of pineapples include alcohol, different types of acids and vinegar. The reports of Sabahelkhier et al. (2010) recommended pineapple in the treatment and convalescence of some diseased conditions.
The aim of this study is to comparatively assess the bacterial composition and antibacterial characteristics of pineapple fruit pulp and bark peels. Besides contributing to the current database on the subject matter, this study will also highlight the potential risk associated with consuming street vended fruits thereby creating public awareness. This study is motivated by the current amount of pineapple fruit juice available in the market without sufficient scientific results to support their suitability for consumption. As well as the need to investigate the anti-microbiological potential of these products and byproducts. More so, the bark peels are often discarded as waste product, hence, the study may highlight possible use for this waste product, which happen to be substantial. Furthermore, the present study aims to screen for the potential presence of microbial contaminants (foodborne pathogens) in the fresh fruit pulp used for juice or consumed directly through microbial isolation and identification.

\section{Materials and Methods}

\section{Source of Samples, Sample Collection and Experimental Design}

Nine pineapple fruits of varying sizes, prices and external morphology were purchased from New Benin market, Ikpoba Hill Benin City, Southern, Nigeria. The fruit samples were immediately transported in sterilized polyethene bags to the laboratory where they were rinsed with distilled deionized water and then washed with $70 \%$ ethanol. The pineapple fruits were fully matured, ripe and fresh. Taxonomic identification was done by specialists in the Department of Plant Biology and Biotechnology, University of Benin. The fruits were procured at the same market but on enquiry about their sources, the sellers said they were supplied from different farms in and around Edo state, Southern Nigeria. They were transported in a different bags to Microbiology Department laboratory, University of Benin, Nigeria for subsequent study. Chemicals and reagents used in this study were of analytical grades and verified by Laboratory technicians in the Department of Microbiology, University of Benin. The experimental design consist of three treatments with three replicates each. The treatments consist of pineapple fruits with different morphology. The fruit peels and pulps will be accessed to determine their antibacterial characteristics and bacterial composition.

Preparation of Samples and Preparation of Aqueous and Ethanol Extract

The fresh fruits were hand peeled to separate the pulp from the bark using a sterilized knife. Sterile gloves were worn 
at all times to prevent cross contamination, which were changed after cutting each fruit. After cutting, they were rinsed in warm distilled water and dried at room temperature. The fruits were weighed prior to cutting as well as general morphological description of the fruits were carried out. Hundred grams of the pulp and peel were used for the study. These were air-dried for 14 days, ground into powder and then sieved with a $0.50 \mathrm{~mm}$ mesh. The powdered extract were thereafter stored in clean bottles at $28 \pm 2^{\circ} \mathrm{C}$ until needed for use. We dispensed the powdered peels into 900 $\mathrm{mL}$ of distilled deionized water, stirred intermittently with a sterile magnetic stirrer, filtered using a Whatman's filter paper and allowed to stand for $48 \mathrm{~h}$. To obtain the solid crude extract, we evaporated the filtrate at $40^{\circ} \mathrm{C}$ using a water bath. This was also repeated for the ethanol extraction but a rotary evaporator was used to obtain the extract. These extracts were stored until required for use in a refrigerator.

\section{Microbiological Assessment}

To determine total viable bacterial count (TVBC), we used nutrient agar (DifcoTM, USA, pH 7.0 - 7.4), which was prepared as recommended by the manufacturer. With the exception of Salmonella-shigella, which was boiled for 15 mins., all the other media were sterilized by autoclave at standard conditions. One hundred $\mu \mathrm{l}$ of homogenate from each samples was inoculated using sterile pipette by using a sterile glass spreader. Each inoculated plates was then held at $37^{\circ} \mathrm{C}$ for 24 to 28 hours in an incubator. Plates with colonies were counted after incubation and these were multiplied with the dilution factor to get TVBC, which was expressed as colony forming units per $\mathrm{mL}(\mathrm{CFU} / \mathrm{mL})$ for fruit pulp and peels of pineapple fruit.

\section{Enumeration of Bacteria}

To obtain pure culture of bacterial colonies, we streaked the different bacterial colonies (based on their morphology) on the respective media. Thereafter, the plates were incubated at $37^{\circ} \mathrm{C}$ for 24 hours. These pure isolates were preserved and identified on the basis of their morphological and biochemical characteristics as enumerated in Cowan and Steel (1965); Eklund and Lankford (1967); von der Osten et al. (1989); Macfaddin (2000). Genera identification was done using the recommended standards of Buchanan and Gibbons (1974); Cowan (1974). At the end of incubation, colonies were counted and expressed as colony forming unit per $\mathrm{mL}$ of sample homogenates.

\section{Source of Test Microorganisms}

Pure cultures of Staphylococcus aureus, Streptococcus faecalis, Pseudomonas aeruginosa, and Escherichia coli were obtained from the Medical Microbiology Department,
University of Benin, Teaching Hospital, Benin City, Nigeria. They were subjected to biochemical tests to confirm their identity according to Cheesbrough (2000), subcultured in nutrient agar, and stored at $4^{\circ} \mathrm{C}$ until required for use.

\section{Evaluation of Antibacterial Activity}

The antibacterial analysis was done to evaluate the antimicrobial properties of the pineapple fruit pulp and peels using the agar well diffusion technique of Cheesebrough (2000). The organisms to be tested were inoculated into the sterile nutrient agar and incubation for $24 \mathrm{~h}$ at $37^{\circ} \mathrm{C}$. Thereafter, an inoculum is transferred into $5 \mathrm{~mL}$ of nutrient broth, which was then incubated for $2 \mathrm{~h}$ at $37^{\circ} \mathrm{C}$. This served as fresh suspension inoculum. Five mm diameter wells were made with a sterile cork borer and inoculum containing test bacteria spread on solid plates. The aqueous extract of pineapple peels were transferred into the wells. Control treatment was done with sterile distilled water. After incubating the plates for $24 \mathrm{~h}$ at $37^{\circ} \mathrm{C}$, the zones of inhibition (if any) were evaluated according to Girish and Satish (2008).

\section{Determination of the Minimum Inhibitory Concentration}

The lowest concentration of an antimicrobial that is capable of inhibiting, control visible growth, or kill particular microorganisms is described as the minimum inhibitory concentration (MIC). MIC is regarded as a basic laboratory measure of the potential strength of an antimicrobial agent. In this study, four concentrations (i.e. $100 \%, 75 \%, 50 \%$, $25 \%$ ) of pulp and peels were prepared by diluting with distilled water and ethanol. After preparing, the nutrient agar broth, $9 \mathrm{~mL}$ was added in each of the four test tubes labelled $100 \%, 75 \%, 50 \%, 25 \%$, which contained $1 \mathrm{~mL}$ of each concentration of fruit pulp and peels and $0.1 \mathrm{~mL}$ of test pathogen suspension. These were held in a shaker incubator overnight at room temperature. Results were recorded based on turbidity and optical density observed at $600 \mathrm{~nm}$ on U.V. Spectrophotometer.

\section{Determination of Minimum Bactericidal Concentration}

This was done using sterile Muller Hinton agar plates, which were inoculated with each sample from the test of MIC that had no visible growth. The plates were incubated for $24 \mathrm{~h}$ at room temperature. The minimum concentration of extract yielding no visible growth was then recorded as the minimum bactericidal concentration for each test.

\section{Results and Discussion}

Results of the antibacterial and bacteria assessment of three different pineapple pulps and barks are presented in Tables $1-8$. 
The number of viable bacteria cells in the pineapple pulps is presented in Table 1. The result suggest sample A had the highest number of viable bacteria cells followed by sample $B$ while the least number of viable bacteria cells were obtained from sample $\mathrm{C}$.

The bacterial load represented by visibly viable community formation from the three different pineapple barks are presented in Table 2. The result suggests that significant amount of viable bacteria communities can be obtained from pineapple bark. The highest amount of viable cells were obtained from sample A followed by sample $C$ whereas the least amount of viable cells were obtained from sample B.

Characterization of bacteria isolates was conducted for the three different pineapple peels. The result of the characterization is presented in Table 3. The following bacteria isolates were found in the samples Staphylococcus aureus, Bacillus species and Clostridium species the most diversity was obtained in sample A with the three bacteria isolates. In samples $\mathrm{B}$ and $\mathrm{C}$ only 2 bacteria isolates were found to be present.

Table 4 show the results of bacteria isolates characterization from the three different pineapple barks. The result suggests the presence of the following bacteria isolates Staphylococcus aureus, Streptococcus faecalis, Bacillus species and Clostridium species The bark of samples B and C was more diverse with three bacteria isolates found to be present whereas sample A had only 3 bacteria isolates obtained from it.

Result of the zone of inhibition of pineapple juice extracted from the peel against some clinical isolates using alcohol extract is presented in Table 5. The result suggests no zone of inhibition can be found within the range applied in the study. The clinical isolates used included Escherichia coli, Pseudomonas aeruginosa, Staphylococcus aureus, and Streptococcus faecalis.

Result of the zone of inhibition of pineapple bark against some clinical isolates using water and alcohol extract is presented in Table 6 . The result suggests no zone of inhibition can be found within the range of water extract used in the study but at $50 \%$ alcohol extract concentration the zone of inhibition ranged between 13 to $16 \mathrm{~mm}$ for the different samples. The clinical isolates used included Escherichia coli, Pseudomonas aeruginosa, Staphylococcus aureus, and Streptococcus faecalis. The highest zone of inhibition of 16 $\mathrm{mm}$ was obtained for both Staphylococcus aureus and Streptococcus faecalis.

Table 7 presents the minimum inhibitory concentration of $50 \%$ alcohol extract on pineapple bark. The result suggests that except for Pseudomonas aeruginosa $50 \%$ alcohol extract of pineapple juice had good effect producing a neat culture with no visible growth of Escherichia coli, Staphylococcus aureus and Streptococcus faecalis.

Table 1. Bacterial load of pulp of pineapple

\begin{tabular}{ll}
\hline Sample & Bacterial count $(\mathbf{C F U} / \mathbf{m L})$ \\
\hline $\mathrm{A}$ & $4.60 \times 10^{4}$ \\
$\mathrm{~B}$ & $1.19 \times 10^{4}$ \\
$\mathrm{C}$ & $1.95 \times 10^{4}$ \\
\hline
\end{tabular}

Key, $\mathrm{CFU} / \mathrm{mL}=$ colony forming units/milliliter.

Table 2. Bacterial load of the bark of pineapple

\begin{tabular}{ll}
\hline Sample & Bacterial count (CFU/mL) \\
\hline A & $9.10 \times 10^{4}$ \\
B & $2.35 \times 10^{4}$ \\
C & $3.80 \times 10^{4}$ \\
\hline
\end{tabular}

Key, CFU $/ \mathrm{mL}=$ colony forming units/milliliter.

Table 3. Bacterial isolated from the pineapple pulp

\begin{tabular}{ll}
\hline Sample & Bacterial Isolates \\
\hline A & Bacillus species, Staphylococcus aureus, Clostridium species \\
B & Bacillus species and Clostridium species \\
C & Staphylococcus aureus and Bacillus species \\
\hline
\end{tabular}


Table 4. Bacterial isolated from the pineapple bark

\begin{tabular}{ll}
\hline Sample & Bacterial Isolates \\
\hline A & Clostridium species and Streptococcus faecalis \\
B & Bacillus species, Clostridium species and Staphylococcus aureus \\
C & Bacillus species, Clostridium species and Streptococcus faecalis \\
\hline
\end{tabular}

Table 5. Zone diameter $(\mathrm{mm})$ of inhibition of pineapple juice extract against four clinical isolates

\begin{tabular}{lllll}
\hline & \multicolumn{2}{l}{ Alcohol extract concentration $(\mathbf{m m})$} & & $\mathbf{5 0}$ \\
Organisms & $\mathbf{5 \%}$ & $\mathbf{1 0} \%$ & - & - \\
\hline Escherichia coli & - & - & - & - \\
$\begin{array}{l}\text { Staphylococcus } \\
\text { aureus }\end{array}$ & - & - & - & - \\
$\begin{array}{l}\text { Streptococcus } \\
\text { faecalis }\end{array}$ & - & - & & - \\
$\begin{array}{l}\text { Pseudomonas } \\
\text { aeruginosa }\end{array}$ & - & - & - & \\
\hline
\end{tabular}

Key, - = no zone diameter of inhibition, Alcohol $=80 \%$ ethanol, $\mathrm{mm}=$ millimeter

Table 6. Zone diameter $(\mathrm{mm})$ of inhibition of pineapple bark extract against some clinical isolates

\begin{tabular}{|c|c|c|c|c|c|c|}
\hline \multirow[b]{2}{*}{ Organisms } & \multicolumn{3}{|c|}{ Water extract concentration (mm) } & \multicolumn{3}{|c|}{ Alcohol extract concentration (mm) } \\
\hline & $5 \%$ & $10 \%$ & $50 \%$ & $5 \%$ & $10 \%$ & $50 \%$ \\
\hline Escherichia coli & - & - & - & - & - & 13 \\
\hline $\begin{array}{l}\text { Staphylococcus } \\
\text { aureus }\end{array}$ & - & - & - & - & - & 16 \\
\hline $\begin{array}{l}\text { Streptococcus } \\
\text { faecalis }\end{array}$ & - & - & - & - & - & 16 \\
\hline $\begin{array}{l}\text { Pseudomonas } \\
\text { aeruginosa }\end{array}$ & - & - & - & - & - & 14 \\
\hline
\end{tabular}

Table 7. Minimum inhibitory concentration (MIC) of the 50\% Alcohol extracts of pineapple bark against some clinical isolates

\begin{tabular}{ll}
\hline Organisms & MIC of $\mathbf{5 0} \%$ alcohol extract \\
\hline Escherichia coli & Neat \\
Staphylococcus aureus & Neat \\
Streptococcus faecalis & Neat \\
Pseudomonas aeruginosa & $1 / 8$ \\
\hline
\end{tabular}


Table 8 presents the minimum bactericidal concentration of $50 \%$ alcohol extract on pineapple bark. The result suggests that except for Pseudomonas aeruginosa $50 \%$ alcohol extract of pineapple juice had good effect producing a neat culture with no visible growth of Escherichia coli, Staphylococcus aureus and Streptococcus faecalis.

Table 8. Minimum bactericidal concentration (MBC) of 50 $\%$ alcoholic extract of pineapple bark against some chemical isolates

\begin{tabular}{ll}
\hline Organisms & $\begin{array}{l}\text { MBC of 50 \% alcohol } \\
\text { extract }\end{array}$ \\
\hline Escherichia coli & Neat \\
Staphylococcus aureus & Neat \\
Streptococcus faecalis & Neat \\
Pseudomonas aeruginosa & $1 / 4$ \\
\hline
\end{tabular}

The antibacterial characteristics and bacteria composition of pineapple pulp and bark have been investigated using three morphologically different pineapples. The three pineapple samples were distinguished from one another using their fruit morphology, which differed in size, shape, and colouration. There is limited information on the isolation and characterization of microorganism associated with pineapple. More so, the antimicrobial potentials of the crop are not well understood. Therefore, the results reported in this study will fill that void by providing supporting evidence for bacterial composition and antibacterial properties of pineapple. Pineapple is a tropical fruit with huge economic potential that is currently expanding through application of technology in their extraction and use. Hence, in future the fruit, its product and byproduct may assume new roles besides conventional use as food (Ogwu et al. 2013; 2016a).

Microorganisms associated with the samples were expressed as colony forming units per $\mathrm{mL}(\mathrm{CFU} / \mathrm{mL})$ for fruit juices in line with the report of Mahfuza et al. (2016). Regardless of the use of fresh pineapple in the study, visible bacteria colonies were obtained from the peel and bark in the range of $1.19 \times 10^{4}$ to $9.10 \times 10^{4} \mathrm{CFU} / \mathrm{mL}$ (Tables 1 and 2). More viable cells were obtained from the bark than from the peel. This may be attributed to the exposed condition of the bark to atmospheric microorganism. Previous reports by Ogwu and Osawaru (2014); Osawaru et al. (2014) on economic vegetables (okra [Abelmoschus] and jute [Corcho$r u s]$ ) implicated the presence of airborne microorganisms on their phylloplanes. These microorganisms have the potential to alter the biochemical composition of the plant (Osawaru et al., 2013). To this end, Raguati et al. (2015) suggested that the stand out results in bacteria cultivation that was marked by a higher number of colonies may be subcultured to ascertain their longevity and biochemical effects in the plant. Colony shape and size of the bacteria were varied and depended on the type. In addition, each type also shows the ability and resistance in the different environmental conditions, such as resistance to heat, acid solution, salt content, and so on (Rheinheimer, 1980). Generally, bacteria require energy and other materials to build their cells for synthesis their protoplasm or other parts of cell. The prime source to fulfil these requirements may be their plant host. More so, bacteria are dependent on the supply of oxygen substances (which is sourced outside) for growing, survival and reproduction, then the nutrient carrier must contain elements of energy sources, carbon, nitrogen and other inorganic elements, organic molecules, complexes, acid - a fatty acid acids - amino acids, and vitamins. Nutrients in fruids provide energy to maintain body functions, activities and growth of living things, such as water, energy sources, carbon source, nitrogen source, sulfur source, a source of phosphorus, a source of oxygen, a source of electron acceptors, mineral resources, and growth factors (Haribi and Ratih, 2008). For these reasons, Ogwu et al. (2016b), described vegetable and fruits as protective foods, which are required for good health and disease prevention. These essential materials have been reported to be present in pineapple pulp and may be the main reason why the fruit is consumed in large quantities all over the world. Although, our results suggest the presence of and possibly contamination by microorganisms. This may have resulted from improper handling of the fruits. More so, it may be due to the poor washing of fruits, utensils associated with the handling of the fruits as well as personal hygiene of the vendors (Tambekar et al., 2008a and b; Chukwu et al., 2010). The results from this study also suggest that pineapple pulp is associated with less number of bacteria compared to the bark. This could be due to the highly acidic nature of the pineapple peels (Mahfuza et al. 2016). In a related study, Nwachukwu and Chukwu (2013) reported TVBC of $3.5 \times$ $10^{5} \mathrm{CFU} / \mathrm{g}$ in pineapple. Eni et al. (2010) also reported a TVBC in the range of $1.3 \times 10^{6}$ to $3.0 \times 10^{7} \mathrm{CFU} / \mathrm{g}$. Another study by Oranusi and Olorunfemi (2011) reported a TVBC of $2.0 \times 10^{6} \mathrm{CFU} / \mathrm{g}$ in pineapple, which is much higher than what we obtained from our experiment. The difference in the results may be due to the different morphological variants used in the study as well as the growth and post-harvest handling conditions.

Microorganisms related fruit spoilage often results from visible colony formation or of large-scale microbial growth i.e. after proliferation. This will then produce off-aroma and flavour due to sugar fermentation and soft-rot/water soak and sliminess from enzyme interactions (Batholomew, 
2008; Barth et al., 2009).Isolation of bacteria includes several activities, among others, dilution at planting, incubation, purification, enrichment, and storage (Hadioetomo, 1993). In this study, different bacterial isolates were identified based on agar colony morphology and biochemical characteristics. The four main microorganisms identified are Staphylococcus aureus, Streptococcus faecalis, Bacillus species and Clostridium species (Tables 3 and 4). The bark had more diverse bacteria assemblage than the peel with all the isolates occurring in samples found on bark whereas in the peel only three isolates were found except for Streptococcus faecalis. Mahfuza et al. (2016) obtained similar group of microorganisms in fruits and vegetable vended in public markets in Bangladesh. The presence of E. coli, Bacillus species and Staphylococcus species, are commonly associated with poor sanitary practices (Oranusi et al., 2006; Oranusi and Olorunfemi, 2011). This was also the case for Streptococcus faecalis and Clostridium species, which can be found in the soil, sewage and faeces. According to Bryan (1977), ambient conditions may lead to the proliferation of bacterial in fruit juices. More so, the results of Visvanathan and Kaur (2001) had previously suggested the presence of E. coli, Pseudomonas aeruginosa Salmonella, and Staphylococcus sp. in vegetables and fruits whereas Braide et al. (2012) recorded high microbial loads of Bacillus sp. and Staphylococcus species in fruit. Gram-positive bacteria were most abundant in the study. These bacteria are associated with several human diseases hence their presence in pineapple pose a public health concern, which should be addressed early. Previous results by World Health Organization (WHO) had implicated severe illness and deaths, especially among children in several countries, caused by E. coli (WHO, 2002). The need for proper training, increased awareness and improved personal hygiene practice may assist in reducing the contamination of street vended fruits (Vanderzant and Splittstoesser, 1992; Tambekar et al., 2008a). Another possible source of fruit contamination may be the growth substrate or environment (Ogwu et al., 2015; Ogwu and Osawaru, 2015).

The antibacterial activities of pineapple peel and pulp against four clinical bacterial isolates was examined in the present study to ascertain their potency. Results of the zone of inhibition of pineapple juice extracted from the peel against some clinical isolates using alcohol extract (Table 5) suggests no zone of inhibition can be found within the range applied in the study. The clinical isolates used included Escherichia coli, Pseudomonas aeruginosa, Staphylococcus aureus, and Streptococcus faecalis. Results of the zone of inhibition of pineapple bark against some clinical isolates using water and alcohol extract (Table 6) also suggests no zone of inhibition can be found within the range of water extract used in the study but at $50 \%$ alcohol extract concentration the zone of inhibition ranged between 13 to $16 \mathrm{~mm}$ for the different samples. The highest zone of inhibition of $16 \mathrm{~mm}$ was obtained for both Staphylococcus aureus and Streptococcus faecalis. Plants are an important source of bioactive compounds and many have not been investigated for their antibacterial activity, which may hold key components for novel antibacterial drugs (Nascimento et al., 2000). According to Panda and Bandyopadhyay (2013), bioactive constituents of plant possess specific chemicals structures that suggest their disease preventive and antimicrobial activities. The antibacterial activities of peel extracts and juice varied with the type of test organisms. Peel extracts revealed stronger antimicrobial activity than the pulp against the bacteria isolates. Adham (2015) reported similar result for Citrus medica, where peel extracts were shown to have stronger antimicrobial activity than the pulp against the bacteria isolates. More so, in their study, Escherichia coli was inhibited by peel extracts whereas gram-positive bacteria Staphylococcus auricularis, Streptococcus mitis, Streptococcus pneumoniae showed complete sensitivity against juice of Citrus medica with zone of inhibition. The study of Ashik et al. (2016) suggest pineapple extract was found to be equally effective against both Gram-positive and negative organisms tested when they measured the antibacterial activity pineapple extract at different concentrations by agar well diffusion technique.

The antibacterial and bioactive effects of fruit juices may be associated with their mineral as well as biologically active constituents. Therefore, fruit juices with pronounced bioavailability and retention property of certain minerals may be used as an alternative anti-infective agent in natural medicine (Padmini et al., 2010). Pineapple contains the protease enzyme bromelain, which has several therapeutic properties against conditions such as malignant cell growth, thrombus formation, inflammation, control of diarrhoea, dermatological and skin debridement (Tambekar and Dahikar, 2010). The available evidence suggest the protease enzyme is absorbable orally and has therapeutic effects. In a study by Bansode and Chavan (2013) pineapple fruit juices were subjected to screening against enteric pathogens E.coli, Salmonella paratyphyi and Shigella sonnei, there was significant antimicrobial activity against the pathogens. There are also reports implicating antimicrobial activity of crude extracts from that inhibits various bacteria.

Minimum inhibitory concentration of $50 \%$ alcohol extract on pineapple bark was also assessed for organisms that showed susceptibility (Table 7). None of the organisms had any growth but when another species (Pseudomonas 
aeruginosa) was introduced, growth was observed. The result suggests that except for Pseudomonas aeruginosa $50 \%$ alcohol extract of pineapple juice had good effect producing a neat culture with no visible growth of Escherichia coli, Staphylococcus aureus and Streptococcus faecalis. More so, minimum bactericidal concentration of $50 \%$ alcohol extract on pineapple bark was assessed and similar result was obtained (Table 8). The result suggests that except for Pseudomonas aeruginosa $50 \%$ alcohol extract of pineapple juice had good effect producing a neat culture with no visible growth of Escherichia coli, Staphylococcus aureus and Streptococcus faecalis. This is an indication that pineapple has good inhibitory and bactericidal activities against this pathogen.

\section{Conclusion}

Microorganisms are naturally present on all foodstuff including pineapple and can be brought in by wind, soil, water, animals and humans. Results from this study suggest the presence of bacteria such as Staphylococcus aureus, Streptococcus faecalis, Bacillus species and Clostridium species on pineapple pulp and bark, which may cause contamination of the fruit, health risks to consumers or careless handlers of the fruits and barks as well as changes in the storage ability and marketability of the fruits. These microorganisms are potentially capable of causing food borne infection or intoxication. As the shelf life may be extended or shortened by the presence of these microorganisms. This is an area that future research may explore to produce supporting evidence for the effects of these microorganism on the storage condition of the pineapple fruit peels. The source of these isolates may be from their growth environment, post-harvest conditions including transportation out of the farm, improper fruit handling, poor handler and environmental hygiene, prolonged preservation at ambient environment, and open-air shops without basic safety features, etc. that may eventually lead to their spoilage. It is, therefore, necessary that the farmers and marketers should take necessary precautions in preventing the contamination of the product to reduce their spoilage and the health risk their consumption pose to the consuming public. In addition, before consumption pineapple peels should be washed in warm water. The peels on the other hand due to the high amount bacteria may serve as a good source of fertilizer. These peels should be properly disposed to prevent cross-contamination of other food sources. We also recommend that further study be carried out to elucidate the phytochemical properties of pineapple peels. These may reveal key utilization potential for that part of the plant. Currently, these peels are discarded hence discovery of a key need for them may lead to reduction of waste from pineapple.

Necessary information, training, orientation, monitoring and support facilities and programs for pineapple (and fruit) vendors may help reduce these risks and provide safe and good quality fruits for consumption. Moreover, health-related ministries, department and sectors should be mobilized for quality improvement of street vended fruits in order to avoid disease outbreaks through consumption of street vended fruits. The antibacterial properties highlighted in this study may also be further explore for the manufacture of antimicrobial drugs and products.

\section{Compliance with Ethical Standard}

Conflict of interests: The authors declare that for this article they have no actual, potential or perceived conflict of interests.

Acknowledgment: The authors wishes to appreciate the support of Mr. Raymond O. Aiwansoba and Mr. Nelson Aghogban as well as staff of the Microbiology Department, University of Benin Teaching Hospital, Benin City, Nigeria.

\section{References}

Abbo, E.S., Olurin, T., Odeyemi, G. (2006). Studies on the storage stability of soursop (Annona muricata L.) juice. African Journal Biotechnology, 5, 108-112.

Adham, A.A. (2015). Phytochemical analysis and evaluation antibacterial activity of Citrus medica peel and juice growing in Kurdistan/Iraq. Journal of Applied Pharmaceutical Sciences, 5(10), 136-141.

Alothman, M., Bhat, R., Karim, A.A. (2009). Effects of radiation processing on phytochemicals and antioxidants in plant produce. Trends in Food Science and Technology, 20, 201-212.

Appel, L.J., Sacks, F.M., Carey, V.J., Obarzanek, E., Swain, J.F., Miller, E.R., Conlin, P.R., Erlinger, T.P., Rosner, B.A., Laranjo, N.M., Charleston, J., McCarron, P., Bishop, L.M. (2005). Effects of protein, monounsaturated fat, and carbohydrate intake on blood pressure and serum lipids, results of the OmniHeart randomized trial. Journal of the American Medical Association, 294(19), 2455-2464.

Ashik, A.A., Vishnu, P.V., Gayathri, R., Geetha, R.V. (2016). Evaluation of antimicrobial activity of pineapple extract against selected microbes. International Journal Pharmarceutical Science Review Research, 39(1), 277-278. 
Bansode, D.S., Chavan, M.D. (2013). Evaluation of antimicrobial activity and phytochemical analysis of papaya and pineapple fruit juice against selected enteric pathogens. International Journal of Pharm. and Biosciences, 4, 1176-1184.

Barth, M., Hankinson, T.R., Zhuang, H., Breidt, F. (2009). Microbiological Spoilage of Fruits and Vegetables. In, Sperber, W.H. and Doyle, M. P. (eds.), Compendium of the Microbiological Spoilage 135 of Foods and Beverages, Food Microbiology and Food Safety. Springer Science. 49p. ISBN: 9781441908261 (online)

Bartholomew, D.P., Paul, R.E., Rorbach, K.G. (2003). The pineapple 'Botany, Production and Uses', University of Hawaii Manoa Honolulu, USA.

http,//bookshop.cabi.org/Uploads/Books/PDF/978085995038/ (Accessed 10/07/2017).

Bartolomé, A.P., Rupérez, P., Fúster, C. (1995). Pineapple fruit, morphological characteristics, chemical composition and sensory analysis of red Spanish and smooth cayenne cultivars. Food Chemistry, 53, 75-79.

Baruwa, O.I. (2013). Profitability and constraints of pineapple production in Osun State, Nigeria. Journal of Horticultural Research, 21(2), 59-64.

Bhat, R., Ameran, S.B., Karim, A.A., Liong, M.T. (2011). Quality attributes of star fruit (Averrhoac arambola L.) juice treated with ultraviolet radiation. Food Chemistry, 127, 641-644.

Braide, W., Oranusi, S.U., Otali, C.C. (2012). Microbiological status of processed fruit juice sold in the commercial city of Onitsha. Scholarly Journal of Biological Science, 1(3), 25-30.

Bryan, F.L. (1977). Diseases transmitted by foods contaminated with wastewaters. Journal of Food Protection, 40, 45-56.

Buchanan, R.E., Gibbons, N.E. (1974). Bergey's Manual of Determinative Bacteriology, 8th edn. Baltimore, Williams and Wilkins Co. ISBN: 0683011170 9780683011173

Buck, J.W., Walcott, R.R., Beuchat, L.R. (2003). Recent trends in microbiological safety of fruits and vegetables. Plant Health Progress, 10, 1094-1098.
Cheesbrough, M. (2000) Microbiological Tests. In, Cheesbrough, M., Ed., District Laboratory Practice in Tropical Countries, Part II, Low Priced Edition, Cambridge University Press, Cambridge, 105-130.

Chukwu, C.O.C., Chukwu, I.D., Onyimba, I.A., Umoh, E.G., Olarubofin, F., Olabode, A.O. (2010). Microbiological quality of pre-cut fruits on sale in retail outlets in Nigeria. African Journal of Agricultural Research, 5(17), 2272-2275.

Cowan, S.T. (1974). Cowan and Steel's Manual for the Identification of Medical Bacteria, 2nd edn. Cambridge, Cambridge University Press. ISBN: 0521203996

Cowan, S.T., Steel, K.J. (1965). Manual for the Identification of Medical Bacteria. London, Cambridge University Press. ISBN: 0521047366

Deanna, M.M., Jeffrey, S.B. (2007). Acid-alkaline Balance, Role in Chronic Disease and Detoxification. Alternative therapy, 13(4), 62-65.

Dragsted, L.O., Krath, B., Ravn-Haren, G., Vogel, U.B., Vinggaard, A.M., Bo Jensen, P., Loft, S., Rasmussen, S.E., Sandstrom, T.I., Pedersen, A. (2006). Biological effects of fruit and vegetables. The Proceedings of the Nutrition Society, 65(1), 61-67.

Eklund, C., Lankford, C.E. (1967). Laboratory manual for general microbiology. Prentice-Hall International, Inc., London. 299pp. ISBN: 197001101256

Eni, A.O., Oluwawemitan, I.A., Oranusi, U.S. (2010). Microbial quality of fruits and vegetables sold in Sango Ota, Nigeria. African Journal of Food Science, 4(5), 291- 296.

FAO (2004). Vegetables. Food and Agriculture Organization of United Nations. Rome. 17p. ISBN: 9521048355

Girish, H.V., Satish, S. (2008). Antibacterial activity of important medicinal plants on human pathogenic bacteria, Comparative Analysis. World Applied Sciences Journal, 5, 267-271.

Hadioetomo, R.S. (1993). Basic Microbiology in Practice, Basic Laboratory Techniques and Procedures. Second printing. PT. Gramedia, Jakarta. 78p. ISBN: 0101116000000026967 
Haribi, P., Ratih, D. (2008). Media and Reagents for Microbiology Laboratory. Semarang, University of Muhammadiyah Semarang. 78pp. ISBN: 9786027036109

Hemalatha, R., Anbuselvi, S. (2013). Physicochemical constituents of pineapple pulp and waste. Journal of Chemistry and Pharmaceutical Research, 5(2), 240-242.

Hung, H.C., Joshipura, K.J., Jiang, R., Hu, F.B., Hunter, D., Smith-Warner, S.A., Colditz, G, A, Rosner, B., Spiegelman, D. \& Willett, W.C. (2004). Fruit and vegetable intake and risk of major chronic disease. Journal of the National Cancer Institute, 96(21), 1577- 84.

Joy, P.P. (2010). Benefits and uses of pineapple. Pineapple Research Station, Kerala Agricultural University, Kerala, India. http://www.kau.in/sites/default/files/documents/benefits and uses_of pineapple.pdf (Accessed on $15 / 02 / 2015$ )

Kalia, A., Gupta, R.P. (2006). Fruit Microbiology. In, Hui, Y.H.J., Cano, M.P., Gusek, W., Sidhu, J.W., Sinha, N.K. (ed.). Handbook of Fruit and Fruit processing. Blackwell Publishing. UK. 28p. ISSN: 23062150

MacFaddin, J.F. (2000). Biochemical tests for identification of medical bacteria, 3rd ed. Lippincott Williams and Wilkins, Philadelphia, PA. ISBN: 9780683053180

Mahfuza, I. Arzina, H., Md. Kamruzzaman, M., Afifa, K., Md. Afzal, H., Rashed, N., Roksana, H. (2016). Microbial status of street vended fresh-cut fruits, salad vegetables and juices in Dhaka city of Bangladesh. International Food Research Journal, 23(5), 2258-2264.

Nascimento, G.F., Locatelli, J., Freitas, P.C., Silva, G.L. (2000). Antibacterial activity of plant extracts and phytochemcals on antibiotic resistant bacteria. Brazilian Journal of Microbiology, 31, 247-256.

Nwachukwu, E., Chukwu, C. M. (2013). Effect of chemical treatments on the microbial load of fruits and vegetables. International Journal of Applied Microbiology and Biotechnology Research, 1, 16-19.

Ogwu, M.C., Osawaru, M.E. (2015). Soil characteristics, microbial compostion of plot, leaf count and sprout studies of cocoyam (Colocasia [Schott] and Xanthosoma [Schott], Araceae) collected in Edo state,
Southern Nigeria. Science, Technology and Arts Research Journal, 4(1), 34-44.

Ogwu, M.C. and Osawaru, M.E. (2014). Comparative study of the microflora population on the phylloplane of common okra [Abelmoschus esculentus l. (Moench.)]. Nigerian Journal of Biotechnology, 28, 17-25.

Ogwu, M.C., Oforjamah, I.N., Ahana, C.M., Osawaru, M.E. (2013). Phyloplane assessment of leaf and stalk for consumption and microbial diversity of sweet potato (Ipomoea batatas (L) Lam., Convolvulaceae). Octa Journal of Environmental Research, 1(2), 107-116.

Ogwu, M.C., Osawaru, M.E., Atsenokhai, E.I. (2016a). Chemical and microbial evaluation of some indigenous fruits and nuts. Borneo Science, 37(1), 54-71.

Ogwu, M.C., Osawaru, M.E., Chime, A.O. (2015). Comparative assessment of plant diversity and utilization patterns of tropical home gardens in Edo state, Nigeria. Scientia Africana, 13(2), 146 - 162.

Ogwu, M.C., Osawaru, M.E., Aiwansoba, R.O., Iroh, R.N. (2016b). Status and prospects of vegetables in Africa. Proceedings of NTBA/NSCB Joint Biodiversity Conference; Unilorin, Ilorin, Nigeria. 47-57pp.

Oranusi, S., Olorunfemi, O. J. (2011). Microbiological safety evaluation of street vended ready-to-eat fruits sold in Ota, Ogun state, Nigeria. International Journal of Research in Biological Sciences, 1(3), 27-32.

Oranusi, S., Galadima, M., Umoh, V.J. \& Nwanze, P. I. (2006). Food safety evaluation in boarding schools in Zaria, Nigeria, using the HACCP system. Science Research Essays. 2(10), 426-433.

Osawaru, M.E., Ogwu, M.C., Imarhiagbe, O. (2013). Biochemical characterization of some Nigerian Corchorus L. species. Bayero Journal of Pure and Applied Sciences, 6(2), 69-75.

Osawaru, M.E., Ogwu, M.C., Ogbeifun, N.S. \& Chime, A.O. (2014). Microflora diversity on the phyloplane of wild okra. (Corchorus olitorius L. Jute). Bayero Journal of Pure and Applied Sciences, 6(2), 136-142.

Padmini, E., Valarmathi, A., Usha Rani, M. (2010). Comparative analysis of chemical composition and 
Antibacterial activities of Mentha spicata and Camellia sinensis. Asian Journal of Experimental Biological Sciences, 1(4), 772-7815.

Panda, S., Bandyopadhyay, P.K. (2013). Chemical information from GCMS studies of methanolic leaf extract of Andrographis paniculata and Datura metel and their antibacterial activity against isolated Pseudomonas aeruginosa (pb112) strain. International Journal of Advanced Pharmaceutical Biological Science, 4(1), 909-915.

Raguati, M., Novirman, J., Mardiati, Z., Endri, M. (2015). Exploration of natural probiotics from Pineapple peels (Ananas Comosus) as a Source of Feed Supplements for Ruminants. Journal of Biology, Agriculture and Healthcare, 5(20), 98-104.

Rheinheimer, S. (1980). Aquatic Microbiology. Willey Inter Science Publication Chichester, 225 pp. ISBN: 047127643X

Sabahelkhier, K.M., Hussain, A.S., Ishag, K.E.A. (2010). Effect of maturity stage on protein fractionation, in vitro protein digestibility and anti-nutrition factors in pineapple (Ananas comosus) fruit grown in Southern Sudan. African Journal of Food Science, 4(8), 550-552.

Tambekar D.H., Jaiswal, V.J., Dhanorkar, D.V., Gulhane, P.B., Dudhane, M.N. (2009). Microbial Quality and safety of street vended fruit juices, a case study of Amravati city. Internet Journal of Food Safety, 10, 7276.

Tambekar, D.H., Dahikar S.B. (2010). Antibacterial Potential of Some Herbal Preparation, an Alternative Medicine in Treatment of Enteric Bacterial Infection. International Journal of Pharmacy and Pharmaceutical Sciences, 2, 4-13.
Tambekar, D.H., Gulhane, S.R., Jaisingkar, R.S., Wangikar, M.S., Banginwar, Y.S., Mogarekar, M.R. (2008b). Household Water management: a systematic study of bacteriological contamination between source and point-of-use. American-Eurasian Journal of Agriculture and Environmental Science, 3(2), 241-246.

Tambekar, D.H., Jaiswal, V.J., Dhanorkar, D.V., Gulhane, P.B., Dudhane, M.N. (2008a). Identification of microbiological hazards and safety of ready-to-eat food vended in streets of Amravati City, India. Journal of Applied Bioscience, 7, 195-201.

Vanderzant, C., Splittstoesser, D.F. (1992). Compendium of Methods for the Microbiological Examination of Foods. American Public Health Association. Washington D. C. 44-61p. ISBN: 0875531733

Visvanathan, P., Kaur, R. (2001). Prevalence and growth of pathogens on salad vegetables, fruits and sprouts. International Journal of Hygiene and Environmental Health, 203(3), 205-213.

von der Osten, C.H., Gioannetti, C., Sinskey, A.J. (1989). Design of a defined medium for growth of Corynebacterium glutamicum in which citrate facilitates iron uptake. Biotechnology Letters, 11(1), 11-16.

WHO (2002). WHO Global Strategy for Food Safety, Safer Food for Better Health. In, Food Safety Issues. Geneva. $26 \mathrm{p}$. http://www.who.int/iris/handle/10665/42559 (Accessed on $12 / 03 / 2015)$.

Wiseman, M. (2008). The second World Cancer Research Fund/American Institute for Cancer Research expert report. Food, nutrition, physical activity and the prevention of cancer, a global perspective. Proceeding of Nutritional Society, 67(3), 253-256. 